\title{
Tempol, a Superoxide Dismutase-Mimetic Drug, Ameliorates Progression of Renal Disease in CKD Mice
}

\author{
Wei Ding ${ }^{a}$ Bin Wang ${ }^{b}$ Minmin Zhang ${ }^{b}$ Yong Gu \\ aDivision of Nephrology, Shanghai Ninth People's Hospital, School of Medicine, Shanghai Jiaotong \\ University, Shanghai, bDivision of Nephrology, Huashan Hospital and Institute of Nephrology, Fudan \\ University, Shanghai, China
}

\section{Key Words}

Chronic kidney disease $\bullet$ Fibrosis $\bullet$ Inflammation $\bullet$ Reactive oxygen species

\begin{abstract}
Abstarct
Background: Oxidative stress has been implicated in the pathogenesis of chronic kidney disease (CKD) and antioxidants may ameliorate disease progression. We investigate the beneficial effect of Tempol, a superoxide dismutase-mimetic drug, on progression of disease in a mouse model of CKD. Methods: CKD was surgically induced in C57BL/6 mice by 5/6 nephrectomy. Mice were randomly divided into 3 groups: sham group, 5/6 nephrectomized group ( $\mathrm{Nx}$ ) and $\mathrm{Nx}+$ Tempol $(2 \mathrm{mmol} / \mathrm{l}$ in drinking water). Mice were sacrificed at the end of 12 weeks. Renal function, structure as well as expression of key molecules involved in the pathogenesis of inflammation, fibrosis and progression in mice were measured. Results: Reduced body weight and impaired renal function (elevation on serum creatinine, blood urea nitrogen, urine albumin, segmental sclerosis and tubulointerstitial damage) was demonstrated in Nx mice but was significantly improved by Tempol administration. Nx animals exhibited significantly elevated proinflammatory and profibrotic factors, activation of NF- $\mathrm{kB}$, increased expression of NADPH oxidase related subunits (p47phox, p67phox, gp91phox), and elevated activation of TGF- $\beta /$ Smad3, EGFR, MAPK signaling pathway. Tempol inhibited NF-KB mediated inflammation, TGF- $\beta /$ Smad3-induced renal fibrosis as well as EGFR and MAPK signaling pathway activation. Conclusions: Tempol administration attenuated renal injury in CKD mice through NF-KB, TGF- $\beta /$ Smad3, redox-senstive EGFR activation and c-Raf/MEK/ERK pathways.
\end{abstract}

Copyright (C) 2015 S. Karger AG, Basel

\section{Introduction}

Chronic kidney disease (CKD) is a slow, progressive and irreversible loss of renal function. The pathogenesis of CKD in most cases involves a complex interaction of inflammatory and W. Ding and B. Wang contributed equally 


\section{Cellular Physiology Cell Physiol Biochem 2015;36:2170-2182

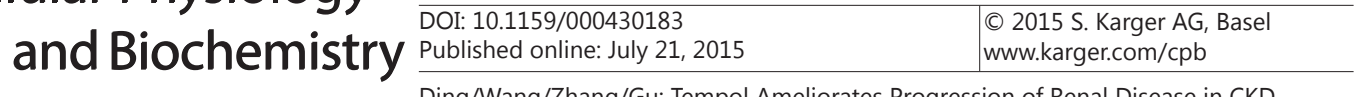

hemodynamic processes, which leads to end stage renal disease (ESRD) characterized by glomerulosclerosis, tubulointerstitial fibrosis and the complete loss of renal function [1]. Oxidative stress is an important feature of CKD and a major mediator of its complications [2]. Reactive oxygen species (ROS) play an important role in normal cellular physiology. However, in pathologic conditions, a surplus of ROS in tissue results in oxidative stress with detrimental consequences such as inflammation and fibrosis. Upregulation of NADPH oxidase, a major source of ROS, has been shown in CKD rats [3]. ROS activates the redoxsensitive NF- $\mathrm{KB}$, which is the general transcription factor for pro-inflammatory cytokines and adhesion molecules that drive the inflammation in CKD [4]. Several lines of evidence point to a central role for inflammation in CKD [5]. The levels of the inflammatory markers TNF- $\alpha$ and IL-6 and the white blood cell count are elevated in CKD [6], although it is not certain whether these changes represent a contribution to, or are a result of, CKD progression.

Transactivation of epidermal growth factor receptor (EGFR) was involved in the progression of CKD $[7,8]$. EGFR was widely expressed in the mammalian kidney including glomerular mesangial cells, proximal tubular and medullary interstitial cells $[9,10]$. Genetic or pharmacologic blockade of EGFR pathway attenuates renal injury [11], suggesting that EGFR signaling acts as a pivotal role in renal development and pathology. EGFR activates downstream mitogen activated protein kinase (MAPK) pathways. The involvement of MAPK pathway has been implicated in several models of kidney disease [12]. Thus, ROS may stimulate MAPK pathways and induce renal injury. For instance, angiotensin II stimulates the production of the superoxide ion through NADPH oxidases and subsequently activates MAP kinases, that leads to renal injury [13].

ROS are important for the pathogenesis of CKD and antioxidants may slow or prevent disease progression [14]. Oxidative stress in CKD is caused by a combination of excessive ROS production and antioxidant depletion. Increased antioxidant defenses may ameliorate progression of renal injury. Nitroxides exert redox metabolic actions and Tempol is the most extensively studied nitroxide [15]. It is a cell membrane permeable amphilite that dismutates superoxide catalytically and limits the formation of toxic hydroxyl radicals. Tempol is effective in detoxifying ROS in cell and animal studies [16]. Administration of Tempol has multiple effects on the kidney. Available data on the effect of administration of Tempol on progression of CKD are limited. In this study, we investigate the beneficial effect of Tempol on progression of disease in CKD mice.

\section{Materials and Methods}

\section{Reagents and antibodies}

Tempol (4 - hydroxyl - 2,2,6,6 - tetramethyl - piperidine - 1 - oxyl) was purchased from Sigma-Aldrich. Antibodies against phospho-IкB, phospho-EGFR, total EGFR, phospho-c-Raf, phospho-MEK1/2, phosphoERK1/2 and phospho-Smad3 were purchased from Cell Signaling Technology. Antibodies against fibronectin (FN), NF- $\kappa$ B P65, CTGF were purchased from Santa Cruz Biotechnology.

\section{Animals and experimental protocol}

Animal study was conducted according to the guidelines for the care and use of animals established by Fudan University. C57BL/ 6 male mice, weighing 22-25 g, were used. CKD in mice was induced by two-stage 5/6 nephrectomy [17]. Mice were randomly segregated into three groups: (1) sham-operated mice and treated with tap water as vehicle (Sham $+\mathrm{V})$; (2) Nx mice were induced by $5 / 6$ nephrectomy and treated with tap water $(\mathrm{Nx}+\mathrm{V})$ and (3) Nx mice were treated with Tempol ( $2 \mathrm{mmol} / \mathrm{l}$ of drinking water) ( $\mathrm{Nx}+\mathrm{Tempol})$. After 12 weeks the mice were sacrificed by exsanguination and kidney was used for histologic, immunohistologic and molecular studies. Section of kidney tissue was affixed in $4 \%$ buffered paraformaldehyde for histological examination and the remainder of kidney was snap-frozen in liquid nitrogen for subsequent protein and mRNA analysis.

Biochemical measurement

Serum creatinine, blood urea nitrogen (BUN) and urinary albumin excretion and creatinine levels were measured by ELISA kits (Exocell) while serum 8-OHdG was determined using mouse 8-OHdG ELISA 


\section{Cellular Physiology Cell Physiol Biochem 2015;36:2170-2182

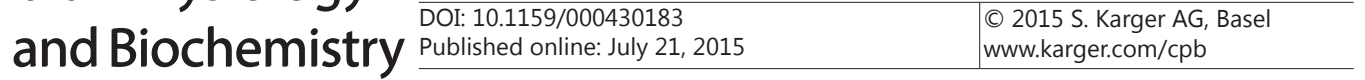 Ding/Wang/Zhang/Gu: Tempol Ameliorates Progression of Renal Disease in CKD}

kit (BMAssay). Renal protein levels of Malondialdehyde (MDA) and thiobarbituric acid reactive substances (TBARS) were detected using commercial kits (Jiancheng Bioengineering Research Institute and Cayman Chemical Company, respectively).

\section{Histologic examination and Immunohistochemistry}

Kidney samples were sectioned at $3 \mu \mathrm{m}$ slices and stained with periodic acid-Schiff reagent (PAS) and Masson's trichrome. Glomerular damage was measured according to published methods [18]. The severity of tubulointerstitial damage was graded according to interstitial collagen deposition using Masson's trichrome staining [19]. For immunohistochemistry, paraffin was removed from the sections. The $3 \mu \mathrm{m}$ slices were stained with mouse anti-CTGF (1:200), anti-FN (1:200), and anti-NF- $\kappa B$ p65 antibody, respectively and counterstained with hematoxyal. The average number of CTGF, FN and NF- $\mathrm{KB}$ p65-positive cells in glomerular section was quantified by counting the cells in 20 glomeruli. All histological and immunohistochemistry evaluations were performed without prior knowledge of the experimental group being studied.

\section{Western blot}

Mouse renal protein (30 mg) were denatured in boiling water for $15 \mathrm{~min}$, separated by SDS-PAGE gel and transferred onto nitrocellulose membranes. The blots were blocked with $5 \%$ non-fat dry milk in Trisbuffered saline, followed by incubation for $2 \mathrm{~h}$ with rabbit anti-phospho-EGFR, phospho-IKB, total EGFR, phospho-c-Raf, phospho-MEK1/2, phospho-ERK1/2, or phospho-Smad3 antibody at a dilution of 1:1000, respectively. After washing with Tris-buffered saline and incubated with horseradish peroxidase conjugated secondary antibody (1:2000), the blots were visualized with Enhanced ECL Kits.

\section{Real-time PCR}

Gene expression of mouse p47phox, p67phox, gp91phox, TNF- $\alpha$, IL-1 $\beta$, TGF- $\beta$, collagen IV and GAPDH were analyzed using real-time PCR. Briefly, kidney tissues were homogenized and total RNA was isolated by Invitrogen RNA isolation kit. cDNA synthesis was carried out using Fermentas cDNA synthesis kit. PCR amplication of cDNA was performed with ABI Biosystems 7500 Detection System. Comparative $2^{-\Delta \Delta}$ CT method was used to calculate the relative amounts of target gene. The primers of these target genes were listed in Table 1.

\section{Electrophoresis mobility shift assay (EMSA)}

EMSA methods were used to detect the binding activities of NF- $\kappa \mathrm{B}$ in nuclear extracts. NF- $\kappa \mathrm{B}$ oligonucleotide's sequence was 5'-AGTTGAGGGGACTTTCCCAGGC-3' end-labeled with $\left[\gamma^{-32} \mathrm{P}\right]$-ATP (Beyotime Institute of Biotechnology). Nucleus extracts $(20 \mu \mathrm{g})$ were treated with poly $(\mathrm{dI}-\mathrm{dC})$ and the $\left[\gamma^{-32} \mathrm{P}\right]$ labeled DNA probe in buffer for $20 \mathrm{~min}$ at $37^{\circ} \mathrm{C}$. Then the binding reactions were separated by electrophoresis on $4 \%$ gel at $200 \mathrm{~V}$ for 1 hour. The protein-DNA complex was then visualized by autoradiography and the relative intensity was measured by a scanning densitometer [20].

\section{Statistical analysis}

Results were presented as means \pm SEM. One-way ANOVA for repeated measures was used to compare mean values between two groups. $p<0.05$ was considered to be statistically significant.

Table1. Sequence of primer pairs for real time PCR. GAPDH, glyceraldehyde-3-phosphate dehydrogenase

\begin{tabular}{lll}
\hline Name & Forward primer & Reverse primer \\
\hline P47phox & 5'-CACCGGCTATTTCCCATCCA-3' & 5'-TGTCCTTTGTGCCATCCGT-3' \\
P67phox & 5'-CTGTGGTGTGAGCATACGGT-3' & 5'-TGTCCTTTGTGCCATCCGT-3' \\
gp91phox & 5'-GAGGTTGGTTCGGTTTTGGC-3' & 5'-CTCCGTCCAGTCTCCAACAA-3' \\
TNF- $\alpha$ & 5'-AAGTTCCCAAATGGCCTCCC-3' & 5'-CTTGGTGGTTTGCTACGACG-3' \\
IL-1 $\beta$ & 5'-GCTACCTGTGTCTTTCCCGT-3' & 5'-CGTCACACACCAGCAGGTTA-3' \\
TGF- $\beta$ & 5'-AGCTTTGCAGGGTGGGTATC-3' & 5'-CCTTCGGGTGAGACCACAAA-3' \\
Collagen IV & 5'-CACCGTTCGTTGAATGCCAG-3' & 5'-AAACCTGGCACCTGCTGATT-3' \\
GAPDH & 5'-TCAGCCGCATCTTCTTTTG-3' & 5'-AAATCCGTTGACTCCGACC3' \\
\hline
\end{tabular}




\section{Cellular Physiology Cell Physiol Biochem 2015;36:2170-2182 \begin{tabular}{l|l}
\hline DOI: 10.1159/000430183 & O 2015 S. Karger AG, Basel
\end{tabular} and Biochemistry Published online: July 21, 2015 www.karger.com/cpb

\section{Results}

Body weight and impaired renal function in Nx mice is improved in NX+Tempol mice

The physiological parameters in mice are shown in Fig. 1. Body weight was significantly decreased in $\mathrm{Nx}+\mathrm{V}$ mice relative to Sham $+\mathrm{V}$ mice $(24.8 \pm 0.3 \mathrm{~g}$ versus $30.2 \pm 0.4 \mathrm{~g})$. Final body weight was significantly improved in $\mathrm{Nx}+\mathrm{Tempol}$ mice $(28.1 \pm 0.2 \mathrm{~g})$ relative to $\mathrm{Nx}+\mathrm{V}$ mice although still lower than Sham $+V$ mice (Fig. 1A). Serum creatinine and BUN levels were

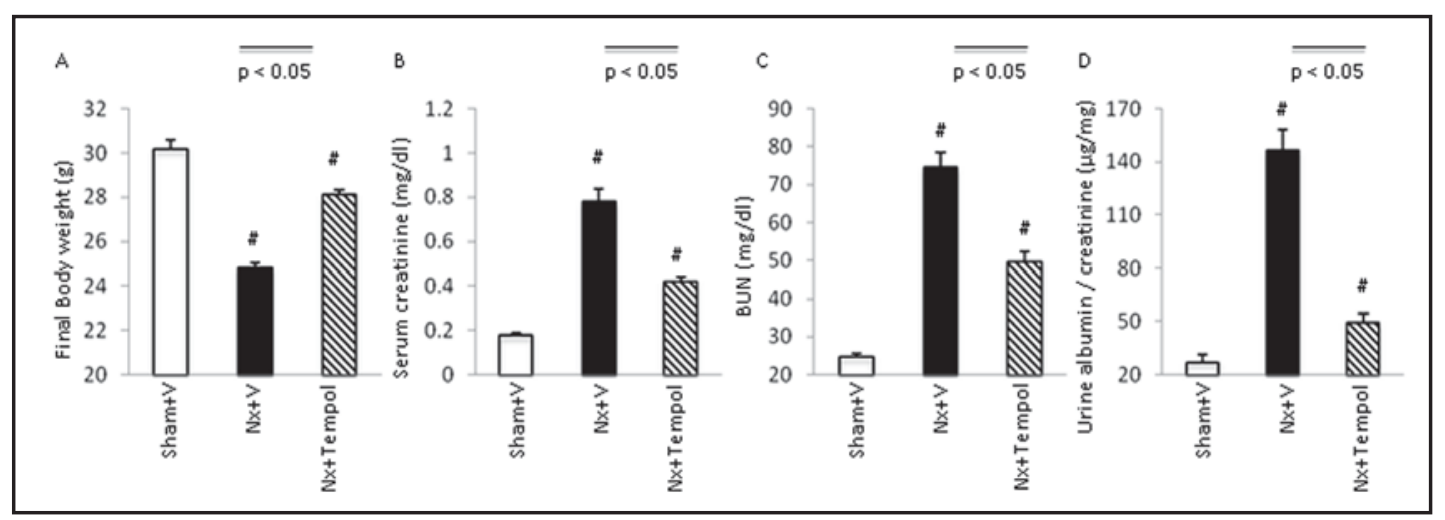

Fig. 1. Physiological parameters in mice at the end of 12 -week study. Three groups of mice were included, $\mathrm{Sham}+\mathrm{V}, \mathrm{Nx}+\mathrm{V}$ and $\mathrm{Nx}+\mathrm{Tempol}$. Mice were fed ad libitum. A: body weight; B: serum creatinine; C: BUN; and D: urine albumin/creatinine ratio. Results are expressed as means $\pm \mathrm{SEM}(\mathrm{n}=8) . \mathrm{Nx}+\mathrm{V}$ and $\mathrm{Nx}+\mathrm{Tempol}$ mice were compared with Sham $+\mathrm{V}$ mice. In addition, $\mathrm{Nx}+\mathrm{V}$ mice were also compared to $\mathrm{Nx}+\mathrm{Tempol}$ mice. ${ }^{\#} p<$ 0.05 .
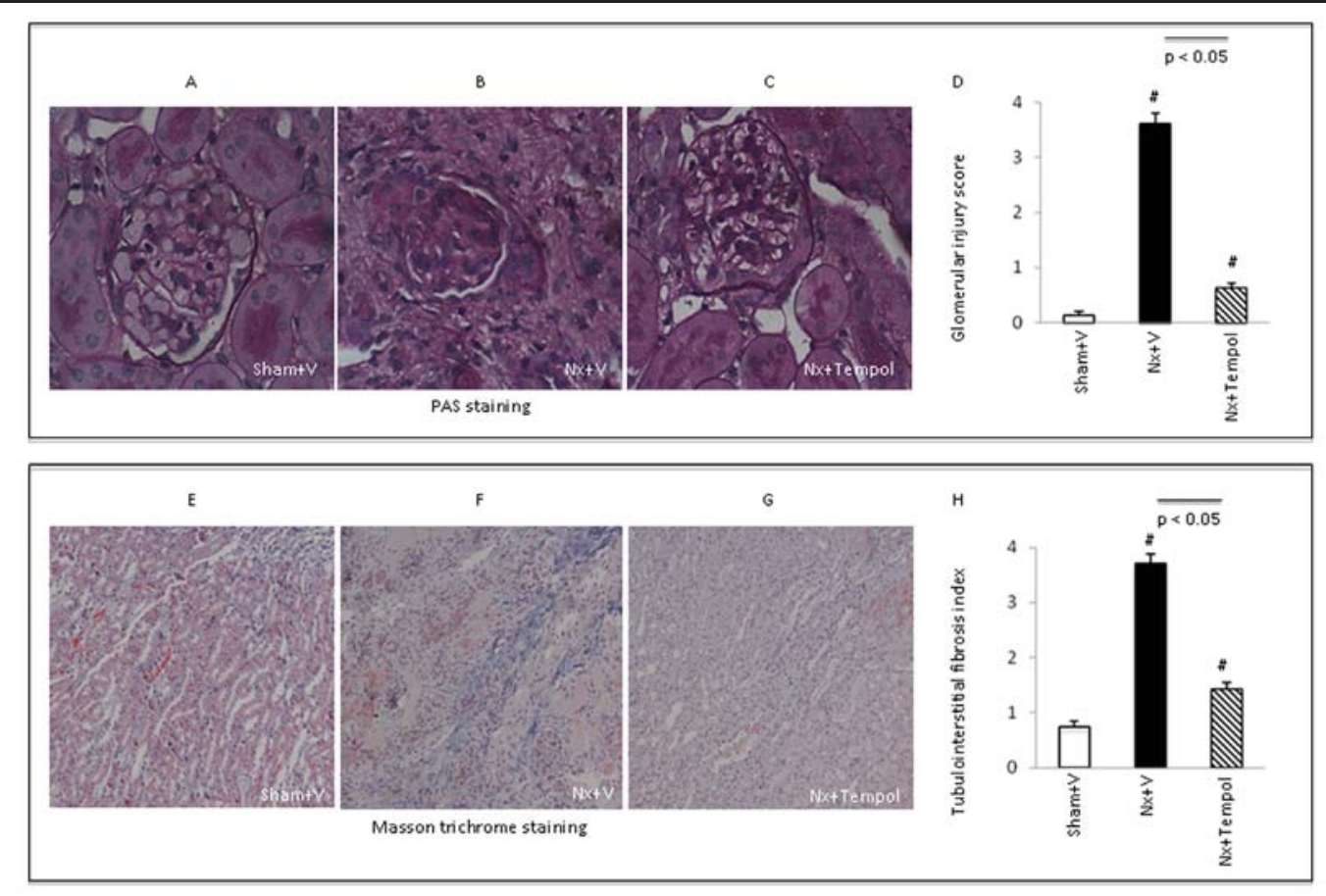

Fig. 2. Kidney histopathology. Representative photomicrographs of PAS-stained kidney sections (A, B \& C, Magnification, $\times 400$ ) and Masson's trichrome-stained kidney sections (E, F \& G, Magnification, $\times 200$ ). A \& E: Sham $+V$ group; $B$ \&F: $\mathrm{Nx}+\mathrm{V}$ group; $\mathrm{C} \& \mathrm{G}$ : $\mathrm{N} x+T e m p o l$ group. Glomerular injury score (D) and tubulointerstitial fibrosis index $(\mathrm{H})$ were evaluated as described in the methods. Values are expressed as means \pmSEM $(n=3) . N x+V$ and $N x+T e m p o l$ mice were compared with Sham $+V$ mice. $\mathrm{Nx}+\mathrm{V}$ mice were also compared to $\mathrm{Nx}+\mathrm{Tempol}$ mice. $" \Rightarrow p 0.05$. 


\section{Cellular Physiology Cell Physiol Biochem 2015;36:2170-2182 \begin{tabular}{l|l|}
\hline DOI: 10.1159/000430183 & ( 2015 S. Karger AG, Basel
\end{tabular} and Biochemistry Published online: July 21, $2015 \quad$ www.karger.com/cpb

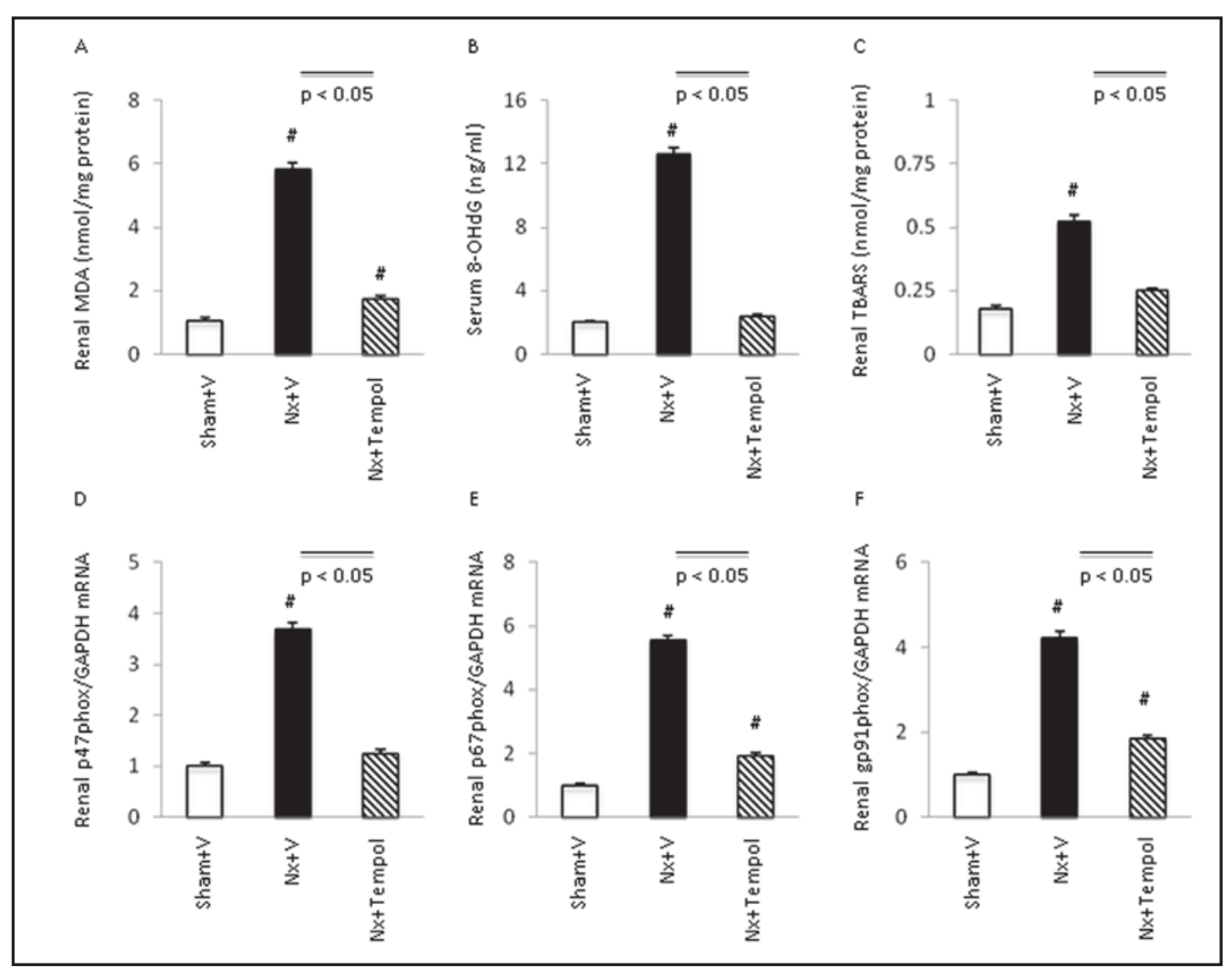

Fig. 3. Reactive oxygen species production in mice. Renal MDA (A), serum 8-OHdG (B) and renal TBARS (C) were measured. Renal mRNA level of p47phox (D), p67phox (E) and gp91phox (F) were detected by real-time PCR and normalized to the expression of GAPDH. Values are expressed as means $\pm \mathrm{SEM}(\mathrm{n}=3) . \mathrm{Nx}+\mathrm{V}$ and $\mathrm{Nx}+\mathrm{Tempol}$ mice were compared with Sham $+\mathrm{V}$ mice. $\mathrm{Nx}+\mathrm{V}$ mice were also compared to $\mathrm{Nx}+\mathrm{Tempol}$ mice. ${ }^{\#} p<0.05$.

elevated in $\mathrm{Nx}+\mathrm{V}$ mice $(0.8 \pm 0.1 \mathrm{mg} / \mathrm{dl}$ and $74.7 \pm 3.8 \mathrm{mg} / \mathrm{dl}$, respectively) than Sham $+\mathrm{V}$ mice $(0.2 \pm 0.0 \mathrm{mg} / \mathrm{dl}$ and $24.8 \pm 0.8 \mathrm{mg} / \mathrm{dl}$, respectively). Serum creatinine and BUN levels were reduced in $\mathrm{Nx}+\mathrm{Tempol}$ mice $(0.4 \pm 0.0 \mathrm{mg} / \mathrm{dl}$ and $49.6 \pm 2.7 \mathrm{mg} / \mathrm{dl}$, respectively) than $\mathrm{Nx}+\mathrm{V}$ mice (Fig. 1B and 1C). Similarly, urine albumin/creatinine ratio was increased in $\mathrm{Nx}+\mathrm{V}$ mice relative to Sham $+V$ mice $(146.6 \pm 11.3 \mu \mathrm{g} / \mathrm{mg}$ versus $27.3 \pm 4.2 \mu \mathrm{g} / \mathrm{mg})$ and was improved in $\mathrm{Nx}+$ Tempol mice (49.1 $\pm 5.1 \mu \mathrm{g} / \mathrm{mg}$ ) (Fig. 1D).

Nx-induced glomerular injury and tubulointerstitial fibrosis is attenuated in NX+Tempol mice

Renal histopathology of $\mathrm{Nx}$ mice was examined. Baseline glomerular injury score for Sham $+V$ mice were shown $(0.14 \pm 0.06)$ (Fig. $2 \mathrm{~A}$ and $2 \mathrm{D}$ ). $\mathrm{Nx}+\mathrm{V}$ mice exhibited severe glomerular injury characterized by cell proliferation, increased extracellular matrix and glomerulosclerosis (3.62 \pm 0.20$)$ (Fig. 2B and 2D). Furthermore, glomerular injury score was significantly reduced in $\mathrm{Nx}+\mathrm{Tempol}$ mice $(0.63 \pm 0.09)$ relative to $\mathrm{Nx}+\mathrm{V}$ mice (Fig. $2 \mathrm{C}$ and $2 \mathrm{D}$ ). Tubulointerstitial fibrosis score in Sham $+\mathrm{V}$ mice was $0.74 \pm 0.12$ (Fig. $2 \mathrm{E}$ and $2 \mathrm{H}$ ). Increased collagen deposition and renal fibrosis was evident in $\mathrm{Nx}+\mathrm{V}$ mice (3.71 \pm 0.18 ) (Fig. $2 \mathrm{~F}$ and $2 \mathrm{H})$. Treatment with Tempol significantly decreased renal interstitial collagen accumulation. Tubulointerstitial fibrosis index was markedly reduced in $\mathrm{Nx}+$ Tempol mice $(1.42 \pm 0.1)$ relative to $\mathrm{Nx}+\mathrm{V}$ mice (Fig. $2 \mathrm{G}$ and $2 \mathrm{H}$ ). 


\section{Cellular Physiology Cell Physiol Biochem 2015;36:2170-2182

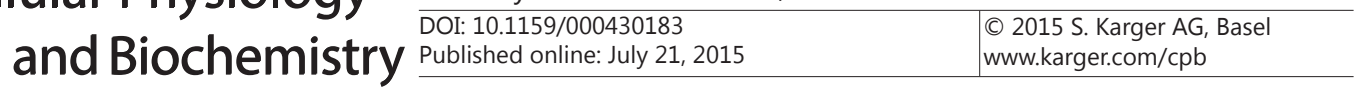

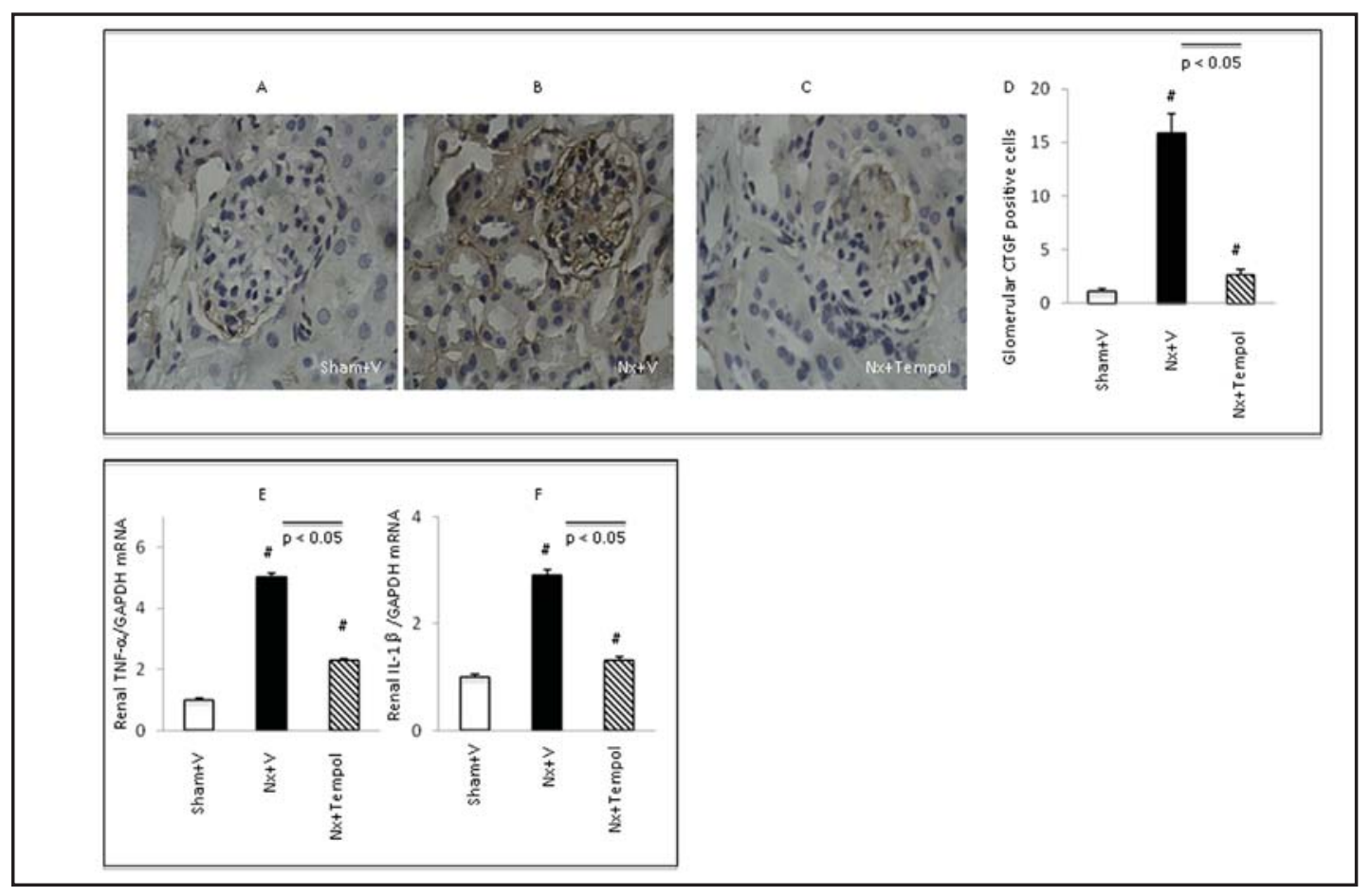

Fig. 4. Expression of inflammatory cytokines in the kidney. Renal CTGF protein expression was detected by Immunohistochemistry (A-D). A: Sham $+\mathrm{V}$ group; $\mathrm{B}: \mathrm{Nx}+\mathrm{V}$ group; $\mathrm{C}: \mathrm{Nx}+\mathrm{Tempol}$ group; $\mathrm{D}$ : Semi-quantitative analysis of CTGF positive cells. Renal mRNA expression of TNF- $\alpha$ (E) and IL-1 $\beta$ (F) were detected by real-time PCR and normalized to the expression of GAPDH. Values are expressed as means \pm SEM $(n=3) . N x+V$ and $\mathrm{Nx}+\mathrm{Tempol}$ mice were compared with Sham $+\mathrm{V}$ mice. $\mathrm{Nx}+\mathrm{V}$ mice were also compared to $\mathrm{Nx}+\mathrm{Tempol}$ mice. ${ }^{\#} p<0.05$.

$N x$-induced oxidative stress is suppressed in $N x+T e m p o l$ mice

Oxidative stress was evaluated by determination of renal MDA and TBARS levels, serum 8-OHdG levels as well as renal mRNA levels of NADPH oxidase subunits p47phox, p67phox and gp91phox. Renal MDA and TBARS protein levels were significantly increased in $\mathrm{Nx}+\mathrm{V}$ mice $(5.8 \pm 0.2 \mathrm{nmol} / \mathrm{mg}$ protein and $0.5 \pm 0.01 \mathrm{nmol} / \mathrm{mg}$ protein, respectively) than Sham $+V$ mice $(1.1 \pm 0.1 \mathrm{nmol} / \mathrm{mg}$ and $0.2 \pm 0.01 \mathrm{nmol} / \mathrm{mg}$, respectively) (Fig. 3A and 3C). Serum 8-OHdG levels were also increased in $\mathrm{Nx}+\mathrm{V}$ mice relative to Sham $+\mathrm{V}$ mice $(12.6 \pm 0.4$ $\mathrm{ng} / \mathrm{ml}$ versus $2.0 \pm 0.1 \mathrm{ng} / \mathrm{ml}$ ) (Fig. 3B). Moreover, renal mRNA levels of $\mathrm{p} 47 \mathrm{phox}$, p67phox and gp91phox were significantly increased in $\mathrm{Nx}+\mathrm{V}$ mice relative to Sham $+\mathrm{V}$ mice (Fig. 3D, 3E and 3F). Treatment with Tempol significantly ameliorated oxidative stress in Nx mice. Serum 8-OHdG levels, renal TBARS protein levels and renal p47phox were normalized in $\mathrm{Nx}+$ Tempol mice whereas renal MDA levels and renal p67phox mRNA and gp91phox mRNA levels were significantly reduced in $\mathrm{Nx}+\mathrm{Tempol}$ mice relative to $\mathrm{Nx}+\mathrm{V}$ mice although still higher than Sham $+V$ mice.

Tempol attenuates renal inflammation and activation of $N F-\kappa B$ in $N x$ mice

Renal immunohistochemistry with CTGF antibody is illustrated in Fig. 4A-C. Compared with Sham $+V$ mice, glomerular cells that were positive for CTGF were significantly increased in $\mathrm{Nx}+\mathrm{V}$ mice $(15.9 \pm 1.1$ versus $1.1 \pm 0.2)$. Treatment with Tempol significantly reduced the number of CTGF positive cells in $\mathrm{Nx}+$ Tempol mice $(2.7 \pm 0.5)$ than $\mathrm{Nx}+\mathrm{V}$ (Fig. 4D). Renal TNF- $\alpha$ and IL-1 $\beta$ mRNA level was significantly elevated in $\mathrm{Nx}+\mathrm{V}$ mice $(5.0$ fold and 2.9 fold, respectively) than Sham $+\mathrm{V}$ mice and treatment with Tempol markedly reduced renal TNF- $\alpha$ and IL- $1 \beta$ mRNA levels relative to $\mathrm{Nx}+\mathrm{V}$ mice (Fig. $4 \mathrm{E}$ and $4 \mathrm{~F}$ ). Renal NF- $\mathrm{kB}$ level 


\section{Cellular Physiology Cell Physiol Biochem 2015;36:2170-2182 \begin{tabular}{l|l|l}
\hline DOI: 10.1159/000430183 & O $2015 \mathrm{~S}$. Karger AG, Basel
\end{tabular} and Biochemistry Published online: July 21, 2015 www.karger.com/cpb

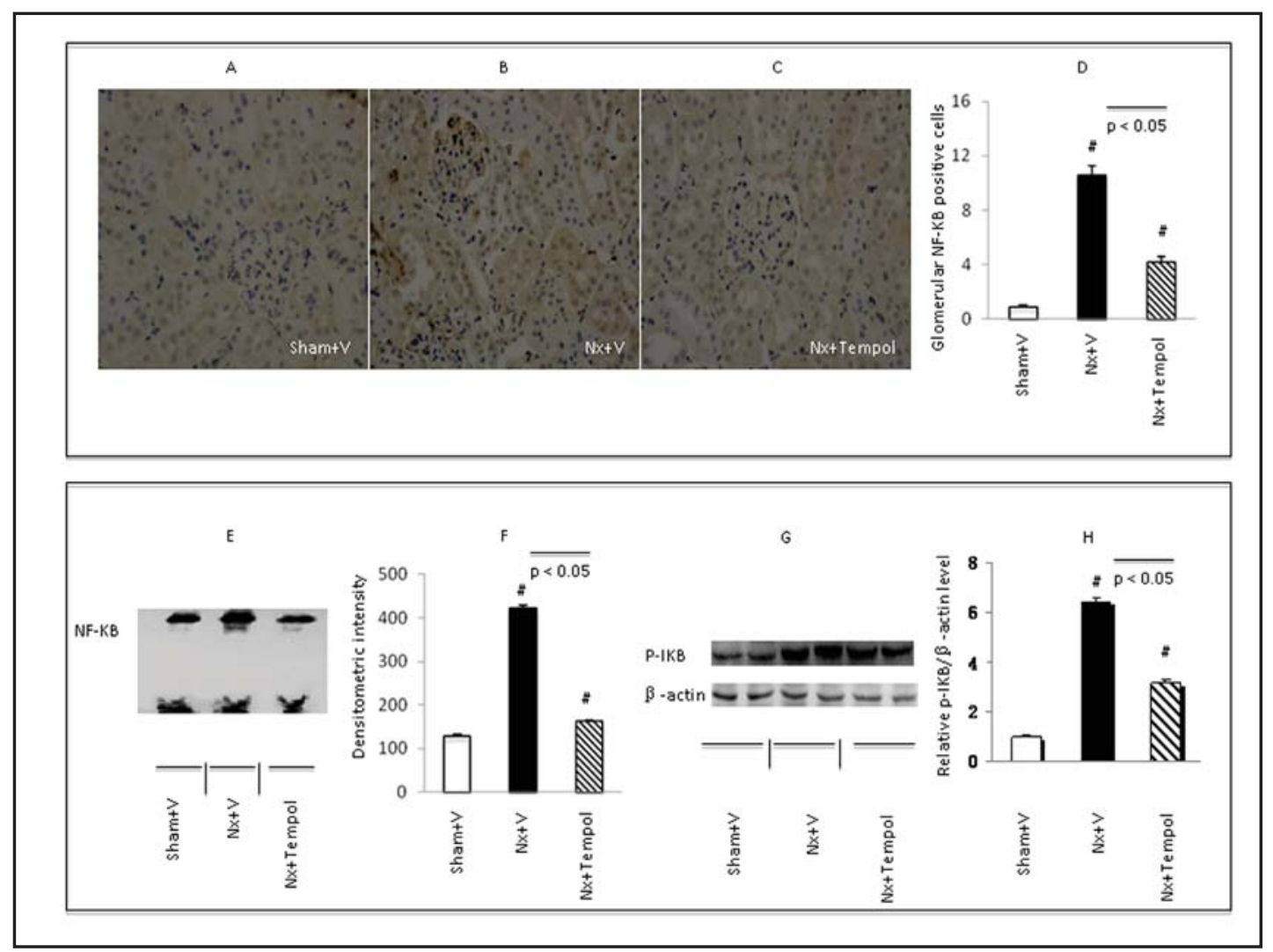

Fig. 5. $\mathrm{NF}-\kappa \mathrm{B}$ expression in mice. Expression of NF- $\kappa \mathrm{B}$ p65 subunit was detected by Immunohistochemistry (A-D). A: Sham $+V$ group; B: $\mathrm{Nx}+\mathrm{V}$ group; $\mathrm{C}$ : $\mathrm{Nx}+\mathrm{Tempol}$ group; D: Semi-quantitative analysis of p65 subunit

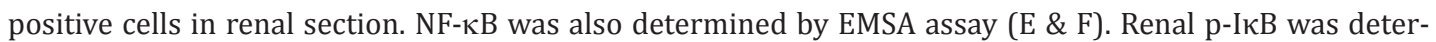
mined by Western blot after normalization to the expression of $\beta$-actin (G \& H). Values are expressed as means \pm SEM $(n=3) . N x+V$ and $\mathrm{Nx}+$ Tempol mice were compared with $\mathrm{Sham}+\mathrm{V}$ mice. $\mathrm{Nx}+\mathrm{V}$ mice were also compared to $\mathrm{Nx}+\mathrm{Tempol}$ mice. ${ }^{\#} p<0.05$.

in Nx mice was quantified using immunohistochemistry, EMSA and western blot (Fig. 5).

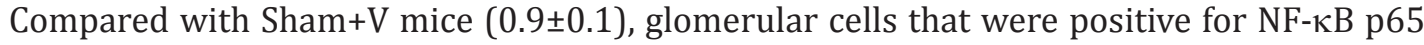
subunit were markedly increased in $\mathrm{Nx}+\mathrm{V}$ mice (10.6 \pm 0.7 ) (Fig. 5D). Treatment with Tempol significantly reduced the number of $\mathrm{NF}-\mathrm{\kappa B}$ positive cells $(4.2 \pm 0.4)$ relative to $\mathrm{Nx}+\mathrm{V}$ mice (Fig. 5D). Similarly, renal NF- $\kappa B-D N A$ binding activity was significantly elevated in $\mathrm{Nx}+\mathrm{V}$ mice compared with Sham $+V$ mice group (422.3 \pm 7.6 unit versus $128.2 \pm 3.9$ unit). NF- $\kappa B-D N A$ binding activity was significantly inhibited in $\mathrm{Nx}+\mathrm{Tempol}$ mice (163.3 \pm 3.1 unit) relative to $\mathrm{Nx}+\mathrm{V}$ mice (Fig. 5F). Similarly, Compared with Sham $+\mathrm{V}$ mice, the I $\mathrm{KB}$ phosphorylation was increased significantly in $\mathrm{Nx}+\mathrm{V}$ mice, and the increment of P-I $\mathrm{B}$ was inhibited by Tempol (Fig. 5G, H).

Tempol attenuates renal fibrogenic pathways in Nx mice

Renal immunohistochemistry with FN antibody is illustrated in Fig. 6A-C. Compared with Sham $+V$ mice, glomerular cells that were positive for FN were significantly increased in $\mathrm{Nx}+\mathrm{V}$ group mice $(8.2 \pm 0.9$ and $0.9 \pm 0.2$, respectively). Treatment with Tempol significantly reduced the number of FN positive cells in $\mathrm{Nx}+\mathrm{Tempol}$ mice $(3.9 \pm 0.3)$ relative to $\mathrm{Nx}+\mathrm{V}$ mice (Fig. 6D). Renal TGF- $\beta$ and collagen IV mRNA levels were significantly increased in $\mathrm{Nx}+\mathrm{V}$ mice (9.3-fold and 4.0-fold, respectively) relative to $S h a m+V$ mice whereas renal TGF- $\beta$ and collagen IV mRNA levels were notably decreased in $\mathrm{Nx}+\mathrm{Tempol}$ mice compared to $\mathrm{Nx}+\mathrm{V}$ mice (Fig. 6E and 6F). We also investigated the significance of TGF- $\beta /$ Smad3 pathway in NADPH 


\section{Cellular Physiology Cell Physiol Biochem 2015;36:2170-2182 \begin{tabular}{l|l|l}
\hline DOI: 10.1159/000430183 & O 2015 S. Karger AG, Basel
\end{tabular} and Biochemistry Published online: July 21, 2015 www.karger.com/cpb}

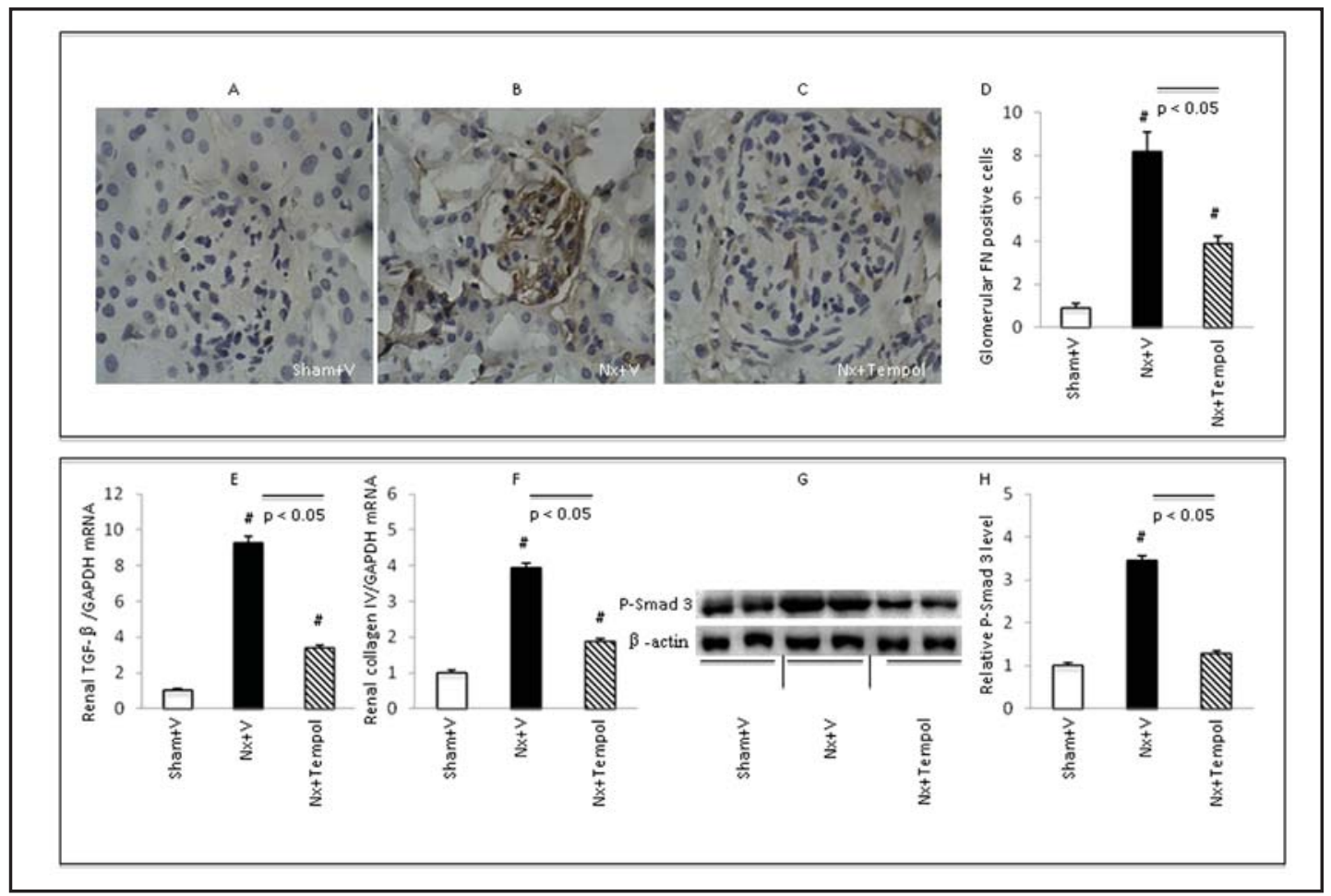

Fig. 6. Expression of fibrotic genes in the kidney. Renal FN protein was detected by Immunohistochemistry (A-D). A: Sham $+V$ group; B: $\mathrm{Nx}+\mathrm{V}$ group; $\mathrm{C}: \mathrm{Nx}+\mathrm{Tempol}$ group; D: Semi-quantitative analysis of FN positive cells. Renal mRNA expression of TGF- $\beta$ (E) and collagen IV (F) were detected by real-time PCR and normalized to the expression of GAPDH. Renal p-Smad3 was determined by Western blot after normalization to the expression of $\beta$-actin ( $G \& H)$. Values are expressed as means $\pm S E M(n=3) . N x+V$ and $N x+T e m p o l$ mice were compared with Sham $+\mathrm{V}$ mice. $\mathrm{Nx}+\mathrm{V}$ mice were also compared to $\mathrm{Nx}+\mathrm{Tempol}$ mice. ${ }^{\sharp} p<0.05$.

oxidase-mediated renal injury. Renal P-Smad3 protein level was significantly increased in $\mathrm{Nx}+\mathrm{V}$ mice (3.4-fold) relative to Sham $+\mathrm{V}$ mice. Importantly, renal P-Smad3 protein level was normalized in $\mathrm{Nx}+\mathrm{Tempol}$ mice (Fig. 6G and 6H).

\section{Tempol attenuates Nx-induced overexpression of EGFR signaling}

We quantified the levels of EGFR and ERK1/2 phosphorylation in mice. Increased phosphorylation of renal EGFR (2.1-fold) was detected in the $\mathrm{Nx}+\mathrm{V}$ mice relative to Sham $+\mathrm{V}$ group, and tempol treatment markedly inhibited this response (Fig. 7A). Phosphorylation of renal c-Raf/MEK/ERK1/2 were significantly elevated (1.89-fold, 3.19-fold and 4.07fold, respectively) in $\mathrm{N} x+\mathrm{V}$ mice compared with Sham $+\mathrm{V}$ group (Fig. 7B-D). Treatment with Tempol significantly reduced the levels of renal p-c-Raf, p-MEK1/2 and p-ERK1/2 protein in $\mathrm{Nx}+$ Tempol mice relative to $\mathrm{Nx}+\mathrm{V}$ mice.

\section{Discussion}

Oxidative stress played a key role in the progression of renal disease. ROS accelerate the development of renal injury by promoting inflammation and intracellular signaling pathways [2,21]. NADPH oxidase is a major source of ROS in kidney disease. Renal MDA and TBARS levels, serum 8-OHdG levels as well as renal mRNA levels of NADPH oxidase subunits p47phox, p67phox and gp91phox were significantly increased in $\mathrm{Nx}+\mathrm{V}$ mice (Fig. 3). Our results are in agreement with previous reports in which increased expression of NADPH oxidase is an important cause of oxidative stress in remnant kidney model [22]. Oxidative 


\section{Cellular Physiology Cell Physiol Biochem 2015;36:2170-2182 \begin{tabular}{l|l}
\hline DOI: 10.1159/000430183 & O 2015 S. Karger AG, Basel
\end{tabular} and Biochemistry Published online: July 21, 2015 www.karger.com/cpb

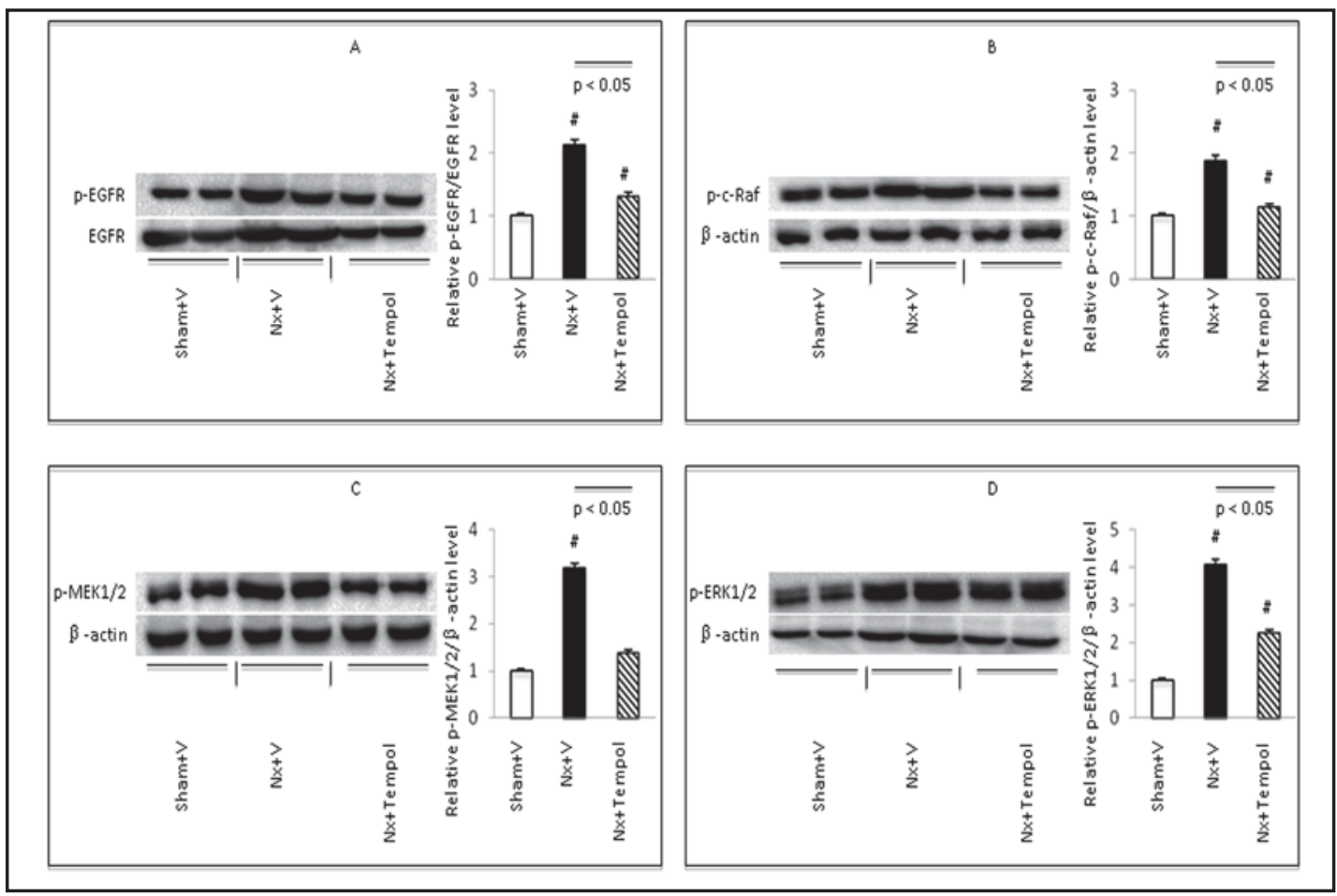

Fig. 7. EGFR and MAPK signaling expression in mice. Protein expression of p-EGFR (A), p-c-Raf (B), p-MEK1/2 (C) and p-ERK1/2 (D) were measured by western blot. Values are expressed as means \pm SEM $(\mathrm{n}=3) . \mathrm{Nx}+\mathrm{V}$ and $\mathrm{Nx}+\mathrm{Tempol}$ mice were compared with $\mathrm{Sham}+\mathrm{V}$ mice. $\mathrm{Nx}+\mathrm{V}$ mice were also compared to $\mathrm{Nx}+\mathrm{Tempol}$ mice. ${ }^{*} p<0.05$.

stress in CKD is not only the result of increased generation on ROS but also because of the depletion of antioxidant defenses. Recently, Dornas et al showed that antioxidant treatment with tempol could reduce blood pressure and suggested that ROS may play a role in the pathogenesis of increased blood pressure in the hypertension models [23]. In present study, we demonstrated that Tempol, a superoxide dismutase-mimetic drug, attenuated renal injury in CKD mice through NF- $\kappa B$, TGF- $\beta /$ Smad3, redox-senstive EGFR activation and c-Raf/ MEK/ERK pathways.

At the end of the 12-week study, final body weight and renal function (serum creatinine, BUN and proteinuria) was significantly improved in $\mathrm{Nx}+\mathrm{Tempol}$ mice relative to $\mathrm{Nx}+\mathrm{V}$ mice (Fig. 1). As expected, the remnant kidney in the $\mathrm{Nx}+\mathrm{V}$ mice showed significant glomerulosclerosis and tubulointerstitial damage. Importantly, glomerulosclerosis and the extension of tubular injury were reduced by more than one-half in the $\mathrm{Nx}+\mathrm{Tempol}$ mice (Fig. 2). The favorable results seen in $\mathrm{Nx}+\mathrm{Tempol}$ mice are likely related to the antioxidant property of this compound. Indeed, Tempol treatment normalized or significantly reduced markers of oxidative stress in Nx mice (Fig. 3).

Previous studies indicated that Tempol treatment $(1 \mathrm{mmol} / \mathrm{L}$ in drinking water) was incapable of reducing renal oxidative stress and failed to improve renal function and structure in the remnant kidney model [2, 24]. Ding et al also showed that tempol $(1 \mathrm{mmol} / \mathrm{L}$ in drinking water) treatment reduced immunofluorescence for 3-nitrotyrosine and HIF 1A mRNA, but had little impact on polycystic kidney disease [25]. Interestingly, higher dose of Tempol ( $3 \mathrm{mmol} / \mathrm{L}$ in drinking water) reduced food intake and weight gain in normal rats [24]. In the present study, we selected the optimal dose of Tempol as $2 \mathrm{mmol} / \mathrm{L}$ in drinking water. Of note, administration of Tempol $(0.29 \mathrm{mmol} / \mathrm{L}$ to $5.8 \mathrm{mmol} / \mathrm{L})$ modulates serum leptin levels and influences food intake and weight gain in mice [26]. However, the mechanism of energy metabolism of Tempol on CKD is beyond the scope of current investigation. 


\section{Cellular Physiology Cell Physiol Biochem 2015;36:2170-2182 \begin{tabular}{ll|l} 
DOI: 10.1159/000430183 & $\begin{array}{l}\text { O 2015 S. Karger AG, Basel } \\
\text { www.karger.com/cpb }\end{array}$ \\
\cline { 2 - 3 }
\end{tabular}}

The number of glomerular CTGF-positive cells as well as renal TNF- $\alpha$ and IL-1 $\beta$ mRNA levels was significantly increased in $\mathrm{Nx}$ mice but was markedly reduced by the administration of Tempol (Fig. 4). Our findings point to the inhibitory effects of Tempol on activation of pro-inflammatory transcription factors. Oxidative stress activates the redoxsensitive NF- $\mathrm{kB}$, which is the general transcription factor for pro-inflammatory cytokines such as renal TNF- $\alpha$, IL- $1 \beta$ and CTGF and drives the inflammation in CKD. Increased activation of NF- $\kappa B$, as evidenced by increased p65 subunit, was demonstrated in CKD rats. Previously, we showed that pyrrolidine dithiocarbamate, an inhibitor of nitric oxide synthase, attenuated the activation of NF- $\mathrm{KB}$ and aldosterone/salt-induced CKD progression [20], Fujihara showed that inhibition of NF- $\kappa B$ attenuates renal injury in the CKD rodents [27]. In the present study, we found that glomerular cells staining positively for NF- $\kappa B$ p65 subunit was increased in $\mathrm{Nx}+\mathrm{V}$ mice and was significantly reduced in $\mathrm{Nx}+\mathrm{Tempol}$ mice. Treatment with Tempol suppressed the activation of NF- $\kappa B$ in remnant kidney (Fig. 5). We concluded that Tempol at $2 \mathrm{mmol} / \mathrm{l}$ prevents translocation and DNA binding of NF- $\mathrm{KB}$ and, thereby, suppresses renal production of pro-inflammatory cytokines such as TNF- $\alpha$, IL-1 and CTGF in CKD. Our results were in accordance with a recent report. Tempol reduces the activation of NF- $\kappa B$ in a mouse model of acute inflammation [28]. The precise role of NF- $\kappa B$ in human renal disease is uncertain. In human renal disease, there is histologic evidence of NF$\mathrm{B}$ activation in diabetic nephropathy, glomerular disease and AKI. NF- $\kappa B$ activates macrophages and glomerular and tubular cells and correlates with parameters of severity of disease such as proteinuria and inflammation [29]. However, these data are largely descriptive and can only been interpreted as supportive for the role of NF- $\mathrm{\kappa B}$ in promoting inflammation in CKD because inflammation per sec will also promote NF- $\mathrm{KB}$ activation.

Oxidative stress promotes pro-fibrotic responses through TGF- $\beta$ signaling, a key mediator of renal fibrosis in CKD [30]. Inhibition of NADPH oxidase suppressed EMT and matrix protein production in renal tubular epithelial cells and renal fibroblasts [31]. Upregulation of TGF- $\beta$ and its receptors lead to the onset of renal fibrosis while neutralizing TGF- $\beta 1$ activity by anti-TGF- $\beta 1$ antibody ameliorated kidney fibrosis [32, 33]. TGF- $\beta$ binds to its receptor and activates downstream signaling pathway, such as Smad2 and Smad3, and mediate tubular epithelial transforming to myofibroblast and stimulate extracellular matrix production [34]. Redox pathways may regulate TGF- $\beta /$ Smad signaling in the development of renal fibrosis [35]. We demonstrated that Tempol suppressed renal TGF- $\beta$ and collagen IV mRNA level, p-Smad3 level as well as number of glomerular FN cells in Nx mice (Fig. 6). The mechanism of the enhancing effect of ROS on TGF- $\beta$-induced Smad phosphorylation is unclear. Activation of TGF- $\beta$ signaling requires phosphorylation of the type I receptor (ALK5) on serine and threonine residues in the GS domain upon ligand binding, while phosphorylated ALK5 in turn induces phosphorylation of Smad2/3 and thereby initiates downstream signaling events. ALKs phosphorylation is negatively regulated by protein phosphatase (PP1) 1 and PP 2A. There is evidence that PP1 and PP2A are redox-sensitive and ROS is able to activate ALK5 and Smad phosphorylation. In addition to regulating Smad phosphorylation, ROS may also modulate TGF- $\beta$ via Smad-independent pathways, including MAPK members, c-Jun N-terminal kinase (JNK) and p38 [35]. Both JNK and p38 are redox sensitive. Hence, it is possible that ROS may facilitate TGF- $\beta$ induced signaling by enhancing JNK and p38 activation and indirectly induce phosphorylation of Smad3.

EGFR activation plays an important role in the progression of renal vascular and glomerular fibrosis. Increased transactivation of EGFR correlates with interstitial fibrosis in human renal allograft biopsies [36] and angiotensin II-induced renal fibrosis [37]. Thus, inhibition of EGFR signaling may attenuate progression of CKD through the suppression of renal proliferation and fibrosis [38]. Liu and co-workers reported that genetic or pharmacologic blockade of EGFR inhibits renal fibrosis [11]. Wassef et al demonstrated that EGFR inhibition attenuated early kidney enlargement in experimental diabetes [39]. Our study showed that transactivation of EGFR was significantly increased in $\mathrm{Nx}+\mathrm{V}$ mice and was suppressed by Tempol (Fig. 7A). The role of extracellular-regulated kinase (ERK) $1 / 2$ in the transduction of renal proliferation and fibrosis has been described. MEK/ERK signaling 


\section{Cellular Physiology Cell Physiol Biochem 2015;36:2170-2182 \begin{tabular}{l|l|l|}
\hline DOI: 10.1159/000430183 & O 2015 S. Karger AG, Basel
\end{tabular} and Biochemistry Published online: July 21, 2015 www.karger.com/cpb}

mediated renal proliferation via EGFR transactivation in mesangial cells while albumin activated ERK1/2 in human renal epithelial cells through transactivation of EGFR [40, 41]. The c-Raf protein is part of the ERK1/2 pathway as a MAP kinase kinase kinase (MAP3K) that functions downstream of the Ras subfamily of membrane associated GTPases. The most important targets of all Raf enzymes are MEK1 and MEK2. Our study demonstrated that c-Raf, MEK1/2 and ERK1/2 signaling cascades were activated in Nx mice and was suppressed by Tempol treatment (Fig. 7).

In conclusion, the present study demonstrated that Tempol administration attenuated oxidative stress, inflammation, fibrosis and deterioration of the remnant kidney function and structure in mice with renal ablation. Further studies are needed to explore the efficacy of Tempol in the progression of CKD in humans, particularly since the results of other antioxidant therapies are more compelling in animal models than in human diseases. If proven effective, Tempol treatment would be an attractive adjunctive therapy for CKD since it is inexpensive and can be orally administrated.

\section{Acknowledgments}

The work was supported by a grant from the Major State Basic Research Development Program of China (973 Program) (No. 2012CB517700) and the National Natural Science Foundation of China (81270822, 81270009 and 81300590).

\section{Disclosure Statement}

The authors declare that there are no conflicts of interest.

\section{References}

1 Schieppati A, Remuzzi G: Chronic renal diseases as a public health problem: epidemiology, social, and economic implications. Kidney Int suppl 2005;98:S7-S10.

2 Vaziri ND, Dicus M, Ho ND, Boroujerdi-Rad L, Sindhu RK: Oxidative stress and dysregulation of superoxide dismutase and NADPH oxidase in renal insufficiency. Kidney Int 2003;63:179-185.

3 DuPont JJ, Ramick MG, Farquhar WB, Townsend RR, Edwards DG: NADPH oxidase-derived reactive oxygen species contribute to impaired cutaneous microvascular function in chronic kidney disease. Am J Physiol Renal Physiol 2014;306:F1499-1506.

4 Wang JC, Zhao Y, Chen SJ, Long J, Jia QQ, Zhai JD, Zhang Q, Chen Y, Long HB: AOPPs induce MCP-1 expression by increasing ROS-mediated activation of the NF- $\mathrm{B}$ pathway in rat mesangial cells: inhibition by sesquiterpene lactones. Cell Physiol Biochem 2013;32:1867-1877.

5 Ruiz S, Pergola PE, Zager RA, Vaziri ND: Targeting the transcription factor Nrf2 to ameliorate oxidative stress and inflammation in chronic kidney disease. Kidney Int 2013;83:1029-1041.

6 Stenvinkel P: The role of inflammation in the anaemia of end-stage renal disease. Nephrol Dial Transplant 2001;16:36-40.

7 Hamm LL, Hering-Smith KS, Vehaskari VM: Epidermal growth factor and the kidney. Semin Nephrol 1993;13:109-115.

8 Wolf G, Neilson EG: Molecular mechanisms of tubulointerstitial hypertrophy and hyperplasia. Kidney Int 1991;39:401-420.

9 Melenhorst WB, Mulder GM, Xi Q, Hoenderop JG, Kimura K, Eguchi S, van Goor H: Epidermal growth factor receptor signaling in the kidney: key roles in physiology and disease. Hypertension 2008;52:987-993.

10 Zeng F, Singh AB, Harris RC: The role of the EGF family of ligands and receptors in renal development, physiology and pathophysiology. Exp Cell Res 2009;315:602-610.

11 Liu N, Guo JK, Pang M, Tolbert E, Ponnusamy M, Gong R, Bayliss G, Dworkin LD, Yan H, Zhuang S: Genetic or pharmacologic blockade of EGFR inhibits renal fibrosis. J Am Soc Nephrol 2012;23:854-867. 


\section{Cellular Physiology Cell Physiol Biochem 2015;36:2170-2182 \begin{tabular}{l|l|l} 
DOI: 10.1159/000430183 & O 2015 S. Karger AG, Basel
\end{tabular} and Biochemistry Published online: July 21, $2015 \quad$ www.karger.com/cpb

12 Tian W, Zhang Z, Cohen DM: MAPK signaling and the kidney. Am J Physiol Renal Physiol 2000;279:F593-F604.

13 Jaimes EA, Galceran JM, Raij L: Angiotensin II induces superoxide anion production by mesangial cells. Kidney Int 1998;54:775-784.

14 Kotur-Stevuljević J, Peco-Antić A, Spasić S, Stefanović A, Paripović D, Kostić M, Vasić D, Vujović A, JelićIvanović Z, Spasojević-Kalimanovska V, Kornic-Ristovski D: Hyperlipidemia, oxidative stress, and intima media thickness in children with chronic kidney disease. Pediatr Nephrol 2013;28:295-303.

15 Wilcox CS: Effects of tempol and redox-cycling nitroxides in models of oxidative stress. Pharmacol Ther 2010;126:119-145.

16 Manning RD Jr, Tian N, Meng S: Oxidative stress and antioxidant treatment in hypertension and the associated renal damage. Am J Nephrol 2005;25:311-317.

17 Cheung WW, Ding W, Gunta SS, Gu Y, Tabakman R, Klapper LN, Gertler A, Mak RH: A pegylated leptin antagonist ameliorates CKD-associated cachexia in mice. J Am Soc Nephrol 2014;25:119-128.

18 Nagai Y, Yao L, Kobori H, Miyata K, Ozawa Y, Miyatake A, Yukimura T, Shokoji T, Kimura S, Kiyomoto H, Kohno M, Abe Y, Nishiyama A: Temporary angiotensin II blockade at the prediabetic stage attenuates the development of renal injury in type 2 diabetic rats. J Am Soc Nephrol 2005; 16: 703-711.

19 Remuzzi G, Zoja C, Gagliardini E, Corna D, Abbate M, Benigni A: Combining an antiproteinuric approach with mycophenolate mofetil fully suppresses progressive nephropathy of experimental animals. J Am Soc Nephrol 1999;10:1542-1549.

20 Ding W, Yang L, Zhang M, Gu Y: Chronic inhibition of nuclear factor Kappa B attenuates aldosterone/saltinduced renal injury. Life Sciences 2012;90:600-606.

21 Rodríguez-Iturbe B, Pons H, Herrera-Acosta J, Johnson RJ: Role of immunocompetent cells in nonimmune renal diseases. Kidney Int 2001;59:1626-1640.

22 An WS, Kim HJ, Cho KH, Vaziri ND: Omega-3 fatty acid supplementation attenuates oxidative stress, inflammation, and tubulointerstitial fibrosis in the remnant kidney. Am J Physiol Renal Physiol 2009;297:F895-F903.

23 Dornas WC, Silva M, Tavares R, de Lima WG, dos Santos RC, Pedrosa ML, Silva ME: Efficacy of the superoxide dismutase mimetic tempol in animal hypertension models: a meta-analysis. J Hypertens 2015;33:14-23.

24 Quiroz Y, Ferrebuz A, Vaziri ND, Rodriguez-Iturbe B: Effect of chronic antioxidant therapy with superoxide dismutase-mimetic drug, tempol, on the progression of renal disease in rats with renal mass reduction. Nephron Exp Nephrol 2009;112:31-42.

25 Ding A, Kalaignanasundaram P, Ricardo SD, Abdelkader A, Witting PK, Broughton BR, Kim HB, Wyse BF, Phillips JK, Evans RG: Chronic treatment with tempol does not significantly ameliorate renal tissue hypoxia or disease progression in a rodent model of polycystic kidney disease. Clin Exp Pharmacol Physiol 2012;39:917-929.

26 Mitchell JB, Xavier S, DeLuca AM, Sowers AL, Cook JA, Krishna MC, Hahn SM, Russo A: A low molecular weight antioxidant decreases weight and lowers tumor incidence. Free Radic Biol Med 2003;34:93-102.

27 Fujihara CK, Antunes GR, Mattar AL, Malheiros DM, Vieira JM Jr, Zatz R: Chronic inhibition of nuclear factor-kappa B attenuates renal injury in the 5/6 renal ablation model. Am J Physiol Renal Physiol 2007;292:F92-F99.

28 Cuzzocrea S, Pisano B, Dugo L, Ianaro A, Patel NS, Caputi AP, Thiemermann C: Tempol reduces the activation of nuclear factor-kappa B in acute inflammation. Free Radic Res 2004;38:813-819.

29 Sanz AB, Sanchez-Nino MD, Ramos AM, Moreno JA, Santamaria B, Ruiz-Ortega M, Egido J, Ortiz A: NF-Kappa B in renal inflammation. J Am Soc Nephrol 2010;21:1254-1262.

30 Border WA, Noble NA: Transforming growth factor beta in tissue fibrosis. N Engl J Med 1994;331:12861292.

31 Rhyu DY, Yang Y, Ha H, Lee GT, Song JS, Uh ST, Lee HB: Role of reactive oxygen species in TGF-beta1-induced mitogen-activated protein kinase activation and epithelial mesenchymal transition in renal tubular epithelial cells. J Am Soc Nephrol 2005;16:667-675.

32 Ling H, Li X, Jha S, Wang W, Karetskaya L, Pratt B, Ledbetter S: Therapeutic role of TGF-beta-neutralizing antibody in mouse cyclosporin A nephropathy: morphologic improvement associated with functional preservation. J Am Soc Nephrol 2003;14:377-388. 


\section{Cellular Physiology \\ Cell Physiol Biochem 2015;36:2170-2182 and Biochemistry \begin{tabular}{l|l}
\hline DOI: $10.1159 / 000430183$ & (C) 2015 S. Karger AG, Basel
\end{tabular}

33 Yu L, Border WA, Anderson I, McCourt M, Huang Y, Noble NA: Combining TGF-beta inhibition and angiotensin II blockade results in enhanced antifibrotic effect. Kidney Int 2004;66:1774-1784.

34 Wang W, Koka V, Lan HY: Transforming growth factor-beta and Smad signalling in kidney disease. Nephrology (Carlton) 2005;10:48-56.

35 Jiang F, Liu GS, Dusting GJ, Chan EC: NADPH oxidase-dependent redox signaling in TGF- $\beta$-mediated fibrotic responses. Redox Biol 2014; 2: 267-272.

36 Sis B, Sarioglu S, Celik A, Zeybel M, Soylu A, Bora S: Epidermal growth factor receptor expression in human renal allograft biopsies: an immunohistochemical study. Transpl immunol 2004;13:229-232.

37 Chen J, Chen JK, Nagai K, Plieth D, Tan M, Lee TC, Threadgill DW, Neilson EG, Harris RC: EGFR signaling promotes TGFß-dependent renal fibrosis. J Am Soc Nephrol 2012;23:215-224.

38 Flamant M, Bollée G, Hénique C, Tharaux PL: Epidermal growth factor: a new therapeutic target in glomerular disease. Nephrol Dial Transplant 2012;27:1297-1304.

39 Wassef L, Kelly DJ, Gilbert RE: Epidermal growth factor receptor inhibition attenuates early kidney enlargement in experimental diabetes. Kidney Int 2004;66:1805-1814.

40 Huang S, Zhang A, Ding G, Chen R: Aldosterone-induced mesangial cell proliferation is mediated by EGF receptor transactivation. Am J Physiol Renal Physiol 2009;296:F1323-F1333.

41 Reich H, Tritchler D, Herzenberg AM, Kassiri Z, Zhou X, Gao W, Scholey JW: Albumin activates ERK via EGF receptor in human renal epithelial cells. J Am Soc Nephrol 2005;16:1266-1278. 